\title{
環境調和型プリント配線板材料の開発
}

岡本 昌治*，杉山 強*，鈴木 鉄秋*

\section{Development of Earth-Friendly Printed Circuit Materials}

\author{
Masaharu OKAMOTO*, Tsuyoshi SUGIYAMA* and Tetsuaki SUZUKI*
}

*東芝ケミカル株式会社電子部材事業部技術部（テ333-8533＼cjkstart埼玉県川口市領家5-14-25）

*E.P.M.Engineering Section, Electronic Parts and Materials Division, Toshiba Chemical Corporation (5-14-25 Ryoke, Kawaguchi-shi, Saitama 332-8533)

\begin{abstract}
Until now printed wiring board (PWB) materials contain brominated flame-retardantes, and as a result there is concern that dioxin may be generated during combustion, and in the future these materials may be designated as regulation targets. We developed new resin system of UL94 V-0 with nitric and phosphoric flame retardantes. It has high humidity resistance and heat durability. We tackled the development of halogen-free materials ahead of other manufactures in the world, and we have merchandised FR-4 grade products.
\end{abstract}

Key Words: Halogen-Antimony Free, Dioxin, Multilayer

\section{1.はじめに}

国内外でダイオキシン問題が浮上しており，ヨーロッパ ではエコラベルの台頭，法規制の動きが顕著になってきて いる。このようなことを踏まえると，プリント配線板材料 も他のプラスチック材料と同様に環境に対する配慮を行う 必要がある。

従来，コンピュータや一般家電製品に使用されているプ リント配線板材料の大半を占めている FR-4グレードの基 材には，難燃性維持のために臭素を含んだテトラブロムビ スフェノールA型エポキシ樹脂を主に使用している。その ため燃焼焼却時に焼却炉の腐食，基材自体の長期熱劣化等 を促進する臭化水素の発生がある。また，低温焼却時に臭 素化ダイオキシン等の発生が懸念される。もう一方で火災 安全性の指標である難燃性UL-94 V-0取得は必須である。

そこで今回，世界に先駆けてハロゲン系難燃剤をまった く用いず，UL-94 V-0を達成したFR-4グレードの多層プリ ント配線板材料の開発を行った。

\section{2. 開発目標}

環境調和型プリント配線板材料の開発目標は次の通りで ある。

(1) ハロゲン, アンチモンフリーでUL-94 V-0であること。

(2) 耐熱性, $\mathrm{Tg}$, 銅䇴引きはがし強さ等, 一般特性が 現行FR-4と同等であること。

(3) 絶縁信頼性, 電気特性等は従来のFR-4と同等であ ること。
(4) PWB加工性が従来のFR-4と同等であること。

\section{3. 開発の経緯}

\section{1 難燃手法概論}

高分子の難燃機構は一般的に以下の 4 つに分類される。

(1) 界面における熱伝達の制御

(2) 固層における分解速度の制御

(3) 固層における分解生成物の制御

(4) 気相反応の制御

具体的には(1)の方法は脱水反応のような吸熱過程を付 与する方法である。(2)は分解温度を上げて然えにくくす る方法や，逆に可燃性生成物を低い温度で放出し難燃化す る方法であり，(3)については分解ガス中の可燃分を減少 したり，逆に不燃性生成物を発生させる方法である。

逆に(4)の気相反応の制御は燃焼反応に抑制効果をもつ 物質を気相に添加する方法である。

これらの効果を積層板用樹脂に用いられる一般的な難燃 手法にあてはめると，以下のようになる。

(1) 脱水による冷却効果

- 金属水和物等の無機フィラーの使用

(2) 分解温度を上げる

ーマトリックス樹脂の架橋密度の向上

(3) 固体残さを増し可燃性揮発分を抑制

加熱初期に揮発性の小さい酸が生じ，脱水炭化作用 を呈するーリン化合物もしくはリン単体の使用

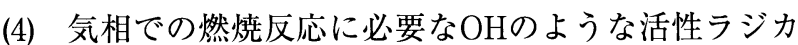
ルの捕捉剤 


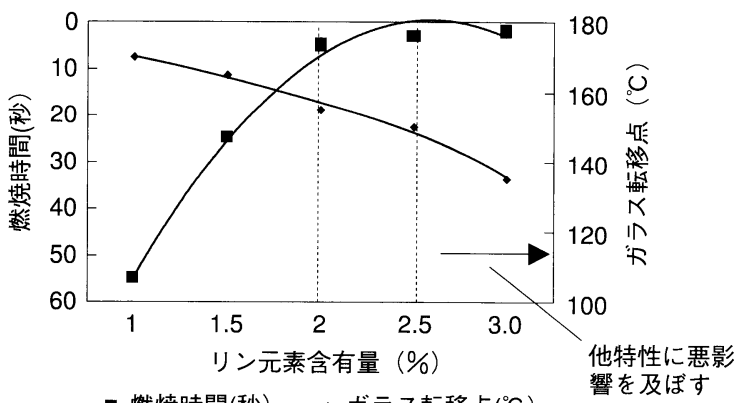

- 燃焼時間(秒) ・ガラス転移点 $\left({ }^{\circ} \mathrm{C}\right)$

図1. リン元素含有量とガラス転移点, 難燃性

ーハロゲン（臭素化エポキシ）の使用

可燃性気体の希釈効果

一窒素系難燃剂の使用

\section{2 難燃手法の検討}

上記の観点から, 臭素化エポキシ樹脂の代替として特に

リン化合物の添加量の検討を行った。

ビスフェノール A 型エポキシ樹脂とノボラックエポキシ 樹脂を $1 ： 1$ に配合したものをモデル樹脂として, モデル 樹脂に対するリン元素含有量を横軸に, 縦軸に硬化後のガ ラス転移点 (DMA法), 平均燃焼時間（UL法）を表した ものを図 1 示す。

リン元素含有量とともに難燃性は増すが，逆にガラス転 移点は低下することがわかる。またリン元素が $2.5 \%$ 以上 になると耐熱性, 吸水性, 耐薬品性等一般特性が著しく低 下することがわかる。

この結果リン元素含有量は $2.0 \%$ か $2.5 \%$ 他特性との バランスが最もよく, リン元素含有量はできるだけ少なく し，その分を前記の脱水による冷却効果を利用するべく金 属水和物等の無機フィラーで難燃性を付与することによっ て，吸湿性，耐熱性等の他特性のバランスが最もよくなる ことが判明した。

\section{4. 開発品の特性}

\section{1 開発品の基板焼却時に発生するガス分析結果}

開発品の基板焼却時に発生するガス分析結果について, $750^{\circ} \mathrm{C} 10$ 分基材燃焼後ガスを補集，抽出後イオンクロマト グラフィで測定したものを以下の図 2 に示す。これを見て みると, 臭素化エポキシ樹脂を使用していない開発品は腐 食性の強い臭化水素の発生がないことがわかる。

次に，ハロゲン化ダイオキシンについて調べた。試料 1 $\mathrm{g}$ を $800^{\circ} \mathrm{C}$ で完全燃焼し，燃焼ガスをすべて捕集した。こ

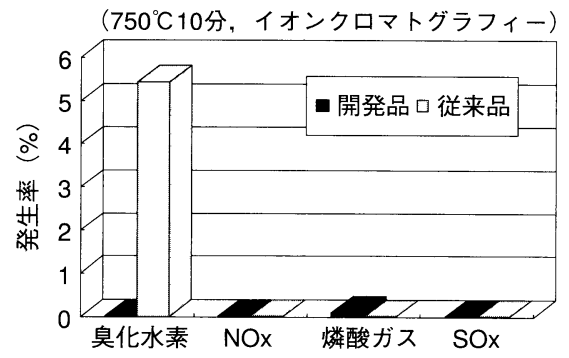

図2. 基板焼却時に発生するガス分析結果
の燃焼ガスの前処理は, 厚生省生活衛生局水道環境部環境 整備課の定める「廃棄物処理におけるダイオキシン類測定 標準マニュアル」の排ガス試料の方法に従った。測定は, GC/MSを用い内部標準物質により, その同定, 定量を行 った。塩素化ダイオキシン類の測定結果を表 1 に, 臭素化 ダイオキシン類の测定結果を表 2 に示す。

本開発品は塩素化ダイオキシン類, 臭素化ダイオキシン 類の発生が見られなかった。

\section{2 開発品の一般特性}

開発品の一般特性を表 3 にレーダチャートで示す。

開発品の一般特性は従来品に比べ難燃性は従来品同様 UL-94 V-0で，ガラス転移点は高く耐熱性に優れ, その他 の特性もほぼ同等の特性である。

表1．塩素化ダイオキシン類測定結果

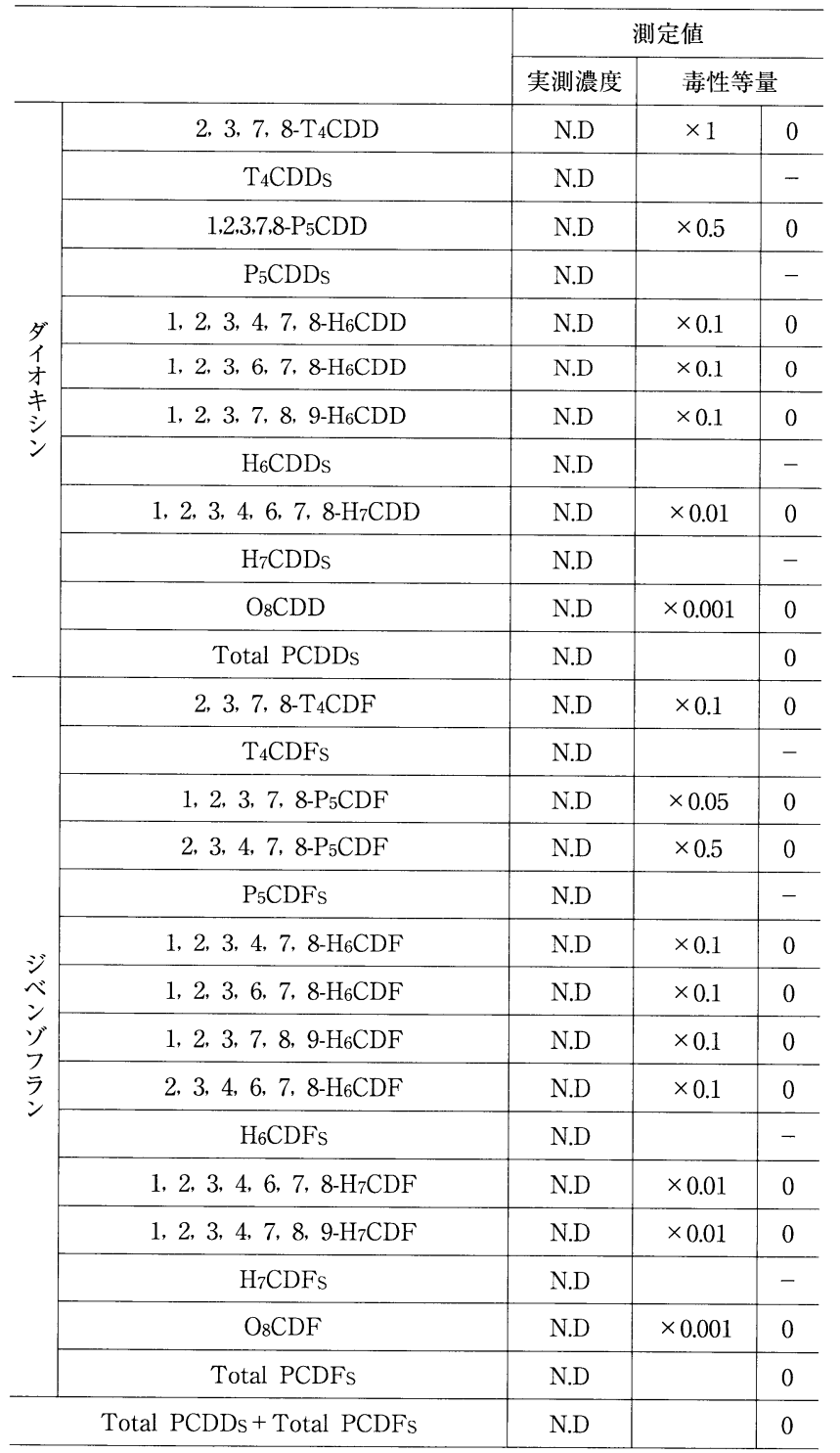

(※1) 実測濃度：ダイオキシン類濃度 $(\mathrm{ng} / \mathrm{g}$ 当たり発生量)

(※2) 毒性等量: $2,3,7,8-\mathrm{T}_{4} \mathrm{CDD}$ 毒性等量 (ng-TEQ/g当たり発生量)

(※3) 毒性等価係数はInternational-TEFを適用

(※4) 実測濃度のND值

$\mathrm{T}_{4} \sim \mathrm{P}_{5} \mathrm{CDD} / \mathrm{DF}: 0.02(\mathrm{ng} / \mathrm{g}$ 当たり発生量) 未満。 $\mathrm{H}_{6} \sim \mathrm{H}_{7} \mathrm{CDD} / \mathrm{DF}: 0.05$ (ng/g当たり発生量) 未満。 $\mathrm{O} 8 \mathrm{CDD} / \mathrm{DF} ： 0.02(\mathrm{ng} / \mathrm{g}$ 当たり発生量）未満。 
表2. 臭素化ダイオキシン類測定結果

\begin{tabular}{|c|c|c|}
\hline & & 実測濃度 \\
\hline & $2,3,7,8-\mathrm{T}_{4} \mathrm{BDD}$ & $\mathrm{ND}<0.02$ \\
\hline & $\mathrm{T}_{4} \mathrm{BDDs}$ & $\mathrm{ND}<0.02$ \\
\hline & $1,2,3,7,8-\mathrm{P}_{5} \mathrm{BDD}$ & $\mathrm{ND}<0.05$ \\
\hline & P5BDDs & $\mathrm{ND}<0.05$ \\
\hline $\begin{array}{l}\text { 多 } \\
1\end{array}$ & $1,2,3,4,7,8-\mathrm{H}_{6} \mathrm{BDD}$ & \\
\hline $\begin{array}{l}\text { 才 } \\
キ\end{array}$ & $1,2,3,6,7,8-\mathrm{H}_{6} \mathrm{BDD}$ & $100-2$ \\
\hline シ & $1,2,3,7,8,9-\mathrm{H}_{6} \mathrm{BDD}$ & $\mathrm{ND}<0.2$ \\
\hline & $\mathrm{H}_{6} \mathrm{BDDs}$ & $\mathrm{ND}<0.2$ \\
\hline & $\mathrm{H}_{7} \mathrm{BDDs}$ & $\mathrm{ND}<1.0$ \\
\hline & $\mathrm{O}_{8} \mathrm{BDDs}$ & $\mathrm{ND}<5.0$ \\
\hline & Total PBDDs & ND \\
\hline & $2,3,7,8-\mathrm{T}_{4} \mathrm{BDF}$ & $\mathrm{ND}<0.02$ \\
\hline & $\mathrm{T}_{4} \mathrm{BDFs}$ & $\mathrm{ND}<0.02$ \\
\hline & $1,2,3,7,8-\mathrm{P}_{5} \mathrm{BDF}$ & $\mathrm{ND}<0.05$ \\
\hline ベ & $2,3,4,7,8-\mathrm{P}_{5} \mathrm{BDF}$ & $\mathrm{ND}<0.05$ \\
\hline ゾ & P5BDFs & $\mathrm{ND}<0.05$ \\
\hline 亏 & $\mathrm{H}_{6} \mathrm{BDFs}$ & $\mathrm{ND}<0.2$ \\
\hline & $\mathrm{H}_{7} \mathrm{BDFs}$ & $\mathrm{ND}<1.0$ \\
\hline & $\mathrm{O}_{8} \mathrm{BDFs}$ & $\mathrm{ND}<5.0$ \\
\hline & Total PBDFs & ND \\
\hline & otal PBDDs + Total PBDFs & ND \\
\hline
\end{tabular}

(※1) 実測濃度：ダイオキシン類濃度 (ng/g当たり発生量)

\section{3 開発品の長期熱劣化特性}

図 3 に開発品の長期熱劣化特性を示す。 従来品に比べ, ガスの発生がないので非常に優れている。

\section{4 開発品の成形性, 加工性}

プレス成形性の 1 つの指標となる, 溶融粘度曲線を図 4 に, 開発品の加工性の 1 つであるドリル磨耗性について図 5 に示す。これを見てみると, 今回の開発品は従来品とほ ほ同等で加工できる。

\section{5 開発品の耐薬品性}

開発品の耐薬品性, 特に黒化処理性, デスミア性, 化学 銅めっき性について以下に述べる。

前述のように従来のFR-4と異なる難燃手法をとってい る。すなわち樹脂変性や添加剤, フィラー等の影響が最も 考えられるのは耐薬品性である。なかでも黒化処理, デス ミア，化学銅めっきはプリント配線板の製造工程のなかで も耐薬品性の厳しい工程であるので，特に以下に述べる。

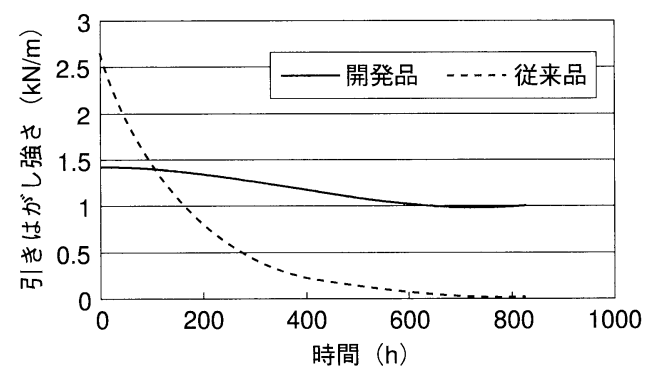

図3. 長期熱劣化特性（銅箔厚：35 $\mu \mathrm{m}$, 処理温度：177 $\mathrm{C}$ )
表3. 開発品の一般特性

\begin{tabular}{|c|c|c|c|c|c|}
\hline 項 & 目 & 単位 & 処理条件 & 従来品 & 開発品 \\
\hline \multicolumn{2}{|l|}{ 体積抵抗率 } & $\Omega \cdot \mathrm{cm}$ & C- $96 / 20 / 65$ & $1 \times 10^{15 \sim 5 \times 10^{15}}$ & $1 \times 10^{15 \sim 5 \times 10^{15}}$ \\
\hline \multicolumn{2}{|l|}{ 表面抵抗 } & $\Omega$ & C- $96 / 20 / 65$ & $1 \times 10^{14 \sim 1 \times 10^{15}}$ & $1 \times 10^{14} \sim 1 \times 10^{15}$ \\
\hline \multicolumn{2}{|l|}{ 絶縁抵抗 } & $\Omega$ & C- $96 / 20 / 65$ & $5 \times 10^{13} \sim 5 \times 10^{14}$ & $1 \times 10^{14 \sim 1 \times 10^{15}}$ \\
\hline \multicolumn{2}{|c|}{ 比誘電率 $(1 \mathrm{MHz})$} & - & C- $96 / 20 / 65$ & $4.6 \sim 4.8$ & $4.6 \sim 4.8$ \\
\hline \multicolumn{2}{|c|}{ 誘電正接（1MHz） } & - & C- $96 / 20 / 65$ & $0.015 \sim 0.020$ & $0.010 \sim 0.020$ \\
\hline \multicolumn{2}{|c|}{ はんだ耐熱性（260 $\mathrm{C} ）$} & $\min$ & $\mathrm{A}$ & $>16$ & $>16$ \\
\hline \multirow{2}{*}{$\begin{array}{l}\text { 引きはがし } \\
\text { 強さ }\end{array}$} & $(18 \mu \mathrm{m})$ & \multirow{2}{*}{$\mathrm{KN} / \mathrm{m}$} & A & 1.5 & 1.3 \\
\hline & $(35 \mu \mathrm{m})$ & & $\mathrm{A}$ & 2.1 & 1.4 \\
\hline \multicolumn{2}{|l|}{ 耐熱性 } & - & E- $0.5 / 250$ & ふくれなし & ふくれなし \\
\hline 曲げ強さ & 縦方向 & $\mathrm{N} / \mathrm{mm}^{2}$ & $\mathrm{~A}$ & $550 \sim 650$ & $540 \sim 630$ \\
\hline \multicolumn{2}{|l|}{ 吸水率 } & $\%$ & $\begin{array}{c}\text { E- } 24 / 50 \\
+D-24 / 23\end{array}$ & $0.05 \sim 0.10$ & $0.02 \sim 0.06$ \\
\hline \multicolumn{2}{|l|}{ 耐燃性（UL94） } & - & $\mathrm{A}$ & $\mathrm{V}-0$ & V-0 \\
\hline \multicolumn{2}{|c|}{ 耐薬品性（NaOH） } & - & A & 3 分異常なし & 3 分異常なし \\
\hline \multirow{3}{*}{ 熱膨張係数 } & 縦方向 & \multirow{3}{*}{$\mathrm{cm} / \mathrm{cm}^{\circ} \mathrm{C}$} & A & $1.3 \times 10^{-5}$ & $1.4 \times 10^{-5}$ \\
\hline & 横方向 & & A & $1.8 \times 10^{-5}$ & $1.9 \times 10^{-5}$ \\
\hline & 厚さ方向 & & A & $4.7 \times 10^{-5}$ & $5.0 \times 10^{-5}$ \\
\hline \multirow{3}{*}{\multicolumn{2}{|c|}{ バーコール硬度 }} & \multirow{3}{*}{ - } & A & 73 & 81 \\
\hline & & & $\mathrm{E}-(2 / 60) / 145$ & 29 & 46 \\
\hline & & & $\mathrm{E}-(2 / 60) / 175$ & 8 & 33 \\
\hline \multirow{4}{*}{ 寸法変化率 } & \multirow{2}{*}{ 縦方向 } & \multirow{4}{*}{$\%$} & エッチング後 & -0.002 & -0.005 \\
\hline & & & E- $0.5 / 170$ & -0.034 & -0.051 \\
\hline & 横方向 & & エッチング後 & -0.001 & -0.003 \\
\hline & 偪力回 & & E-0.5/170 & -0.012 & -0.029 \\
\hline \multirow{2}{*}{ ガラス転移点 } & DMA法 & \multirow{2}{*}{${ }^{\circ} \mathrm{C}$} & \multirow{2}{*}{ A } & $140-160$ & $165-185$ \\
\hline & TMA法 & & & $120-130$ & $120-130$ \\
\hline
\end{tabular}

※1) 試験片の厚さは $1.6 \mathrm{~mm}$

(※2) 試験方法はJIS-C-6481に準拠

\section{5.1 黒化処理性}

開発品，従来品の各基材を $100 \mathrm{~g} / \ell$ の浴負荷で $20 \mathrm{~g} / \ell$ 水 酸化ナトリウム水溶液に $60^{\circ} \mathrm{C} 40$ 時間漬け込んだ。実工程に シミュレートすると, $10000 \mathrm{~m}^{2}$ 処理相当になると考えられる。

その液で黒化処理液を建浴して $90^{\circ} \mathrm{C} 4$ 分黒化処理を行っ た。その銅䇴表面の処理面形状のSEM写真を図 6 に示す。

黒化処理工程での平均的建浴サイクルと考えられる $10000 \mathrm{~m}^{2}$ のレベルでは処理形状に変化は見られなかった。

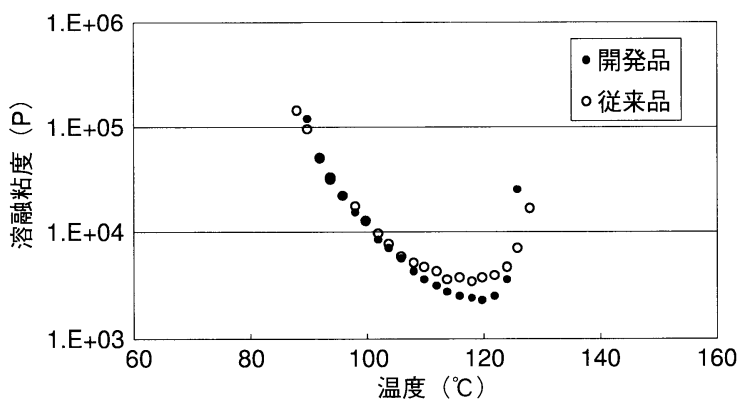

図4. 溶融粘度曲線 $\left(2{ }^{\circ} \mathrm{C} / \mathrm{min}\right)$

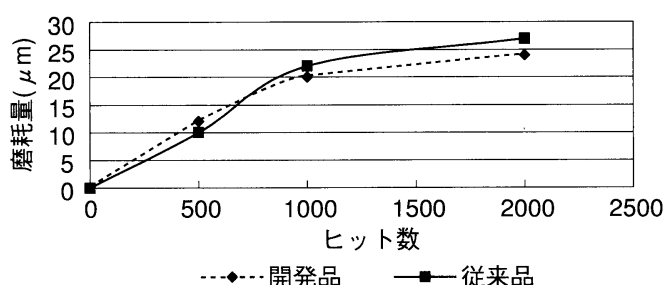

図5. 開発品のドリル磨耗性 


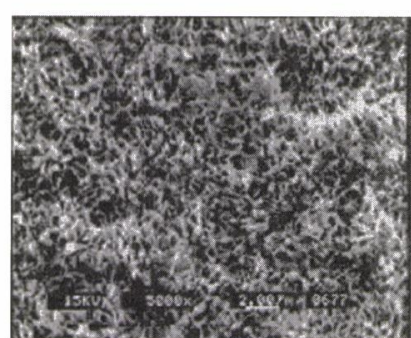

従来品

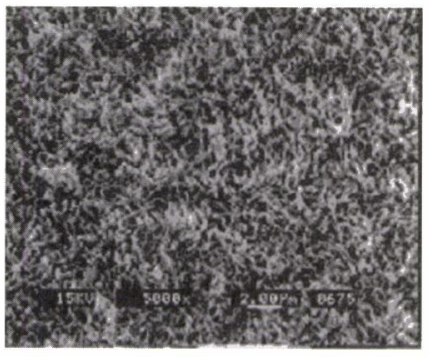

開発品
図6. 黒化処理形状SEM写真

\section{5.2 デスミア性}

各基材のデスミアエッチングレートを表 4 に示す。マト リックス樹脂の硬化密度の違いによるエッチングレートの 違いが懸念されたが, 通常のデスミア工程では問題ないこ とがわかった。

\subsection{3 化学銅めっき性}

化学銅めっき浴に積層板を浸せきし $(50 \mathrm{~g} / \ell)$, 所定時 間浸せき後にその溶出液を用いて化学銅めっき浴を建浴 し，無電解銅めっきを行い，カバーリングの確認を行った。 浸せき積層板は24時間ごとに更新した。この結果を表 5 に 示す。

この結果より, 開発品の化学銅めっき性は従来品とほほ 同等であり，溶出物の影響はなかった。

\section{6 長期信頼性評価}

最後に開発品加工後の長期信頼性評価の 1 つとして, 耐 マイグレーション性試験について，図7に示す。試験条件

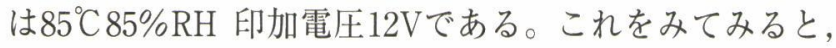

\begin{tabular}{l|c}
\multicolumn{2}{c}{ 表4. デスミアエッチングレート } \\
\hline 測定基材 & 測定結果 $\left(\mathrm{mg} / \mathrm{dm}^{2}\right)$ \\
\hline 従来FR-4 & 30.3 \\
\hline ハロゲンフリー材 & 30.7 \\
\hline
\end{tabular}

表5. 銅めっきカバーリング性

\begin{tabular}{c|c|c|c|c}
\hline \multirow{2}{*}{$\begin{array}{c}\text { 浸せき } \\
\text { 条件 }\end{array}$} & \multicolumn{2}{|c|}{ 従来品 } & \multicolumn{2}{c}{ 開発品 } \\
\cline { 2 - 5 } & $0.9 \phi$ & $0.3 \phi$ & $0.9 \phi$ & $0.3 \phi$ \\
\hline $8 \mathrm{~h}$ & $\bigcirc$ & $\bigcirc$ & $\bigcirc$ & $\bigcirc$ \\
\hline $24 \mathrm{~h}$ & $\bigcirc$ & $\bigcirc$ & $\bigcirc$ & $\bigcirc$ \\
\hline $48 \mathrm{~h}$ & $\bigcirc$ & $\bigcirc$ & $\bigcirc$ & $\bigcirc$ \\
\hline $72 \mathrm{~h}$ & $\bigcirc$ & $\bigcirc$ & $\bigcirc$ & $\bigcirc$ \\
\hline
\end{tabular}

一般的な合格基準である処理時間1000時間において絶縁劣 化はみられない。

\section{5. まとめ}

今回開発を行った環境調和型プリント配線板材料は，リ ンを基本とした新規難燃手法により開発を行った。諸特性 も接着性等, 若干, 従来のものに比べ劣るものの, 実用上 問題ないものとなっている。現在, 一部パソコン等で上市 しており, 今後も世界的な環境調和の意識の高まりからニ ーズは増えていくと思われる。また, 半導体封止材料の八 ロゲンフリー化や鉛フリーはんだの開発等, 基板周辺部品 の環境調和化の動きも大きくなっている。

このように周辺の技術との連携も重要になっている。

また, 環境調和型の技術とは相対しているもう 1 つの技 術ファクタである電子機器の高密度, 小型化のために, 基 板もよりファインなものが求められていく。そのなかで, 次世代型のものとしてビルドアップ型プリント配線板との リンクも必須である。

地球環境を意識するならば，限られた資源のリサイクル 化も重要な課題となっている。

21世紀を迎えるにあたり, 今後は他の材料同様，プリン 卜配線板材料もリサイクル化を常に念頭に扔き，次世代の 開発を行っていくべきであると考える。

(1999.11.2-受理２000.1.25-再受理)

\section{文献}

1) 神戸博太郎 編：“高分子の熱分解と耐熱性”, 培風館, 1974

2) 鈴木鉄秋：“環境調和型多層プリント配線板材料”, 環境 · リサイクル技術ハンドブック，pp.243〜 246, 工業調査会， 1999

3) 八甫谷明彦, 他：“環境調和型多層プリント配線板の開発 · 量産化”, 第13回エレクトロニクス実装学術講演大会講演論 文集，pp.31 32，1999

4) 岡本昌治, 他： “環境調和型プリント配線板材料の開発”, 第13回エレクトロニクス実装学術講演大会講演論文集, pp.115 116, 1999

5) Satoshi Maekawa: "Halogen-Free FR-4 Copper Clad Laminates", Technical Track T3 “Green” Technologies T32-1, Electric Circuits World Convention 8, 1999

試料： $1.1 \mathrm{~mm} 6$ 層板

環境条件 : $85^{\circ} \mathrm{C} \cdot 85 \%$ 印加電圧 : DC12V
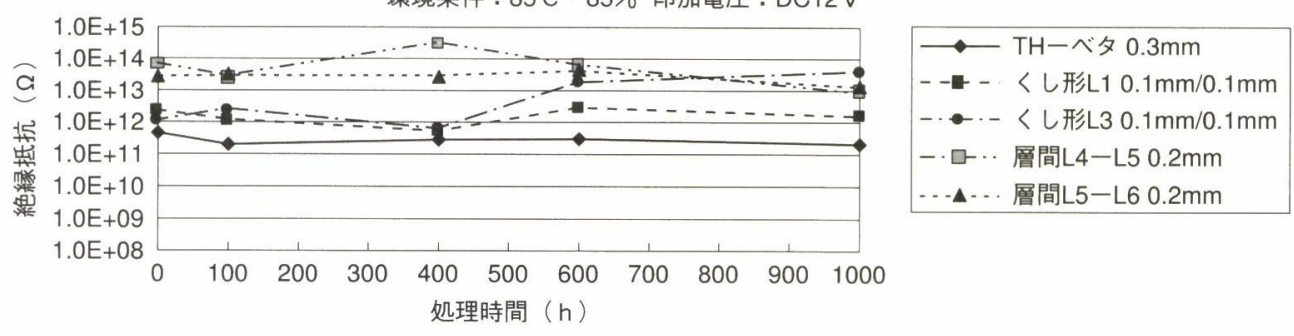

図7. 耐マイグレーション性試験 